San Antonio Review • San Antonio Review (Issue 2 | Winter 2019)

\title{
A School Board Meeting Challenges Faith
}

Bekah S. McNeel

Published on: Dec 04, 2017

Updated on: Aug 08, 2020

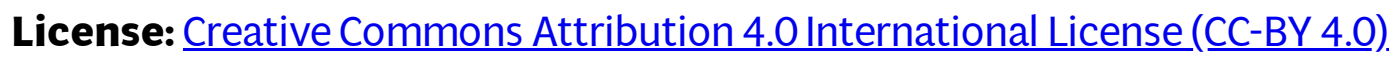


Recently I covered what has been by far the most difficult events of my young journalism career: a school board meeting. I'm an education reporter, and school board meetings feature regularly my calendar. Usually the primary challenge is staying awake.On that Monday night, the primary challenge was keeping my faith.

In August, San Antonio Independent School District added sexual orientation and gender identity to its non-discrimination policy. The policy had been in place for decades, with race, gender, religion and other standard non-discrimination language included. Given the likelihood of bullying and employment discrimination toward LGBTQIA people, the school board decided to do what other major cities have done, and add that population to the policy.

Shortly thereafter, a group of Christians began to mobilize to protest. Wearing "school bus yellow" the group flooded the SAISD board, claiming to be concerned for the rights of those girls who would be "traumatized" by seeing boys in their restrooms and made broad statements about sexual promiscuity, predation, and protecting innocence. They also invoked God's name as they demanded that the district institute an "immutable gender" policy.

In the week leading up to the meeting, word had spread about the protest, and LGBTQIA activist groups began to mobilize. When I arrived at the board meeting, there were 300 people packed into a room that comfortably holds around 100. Forty-nine people signed up to speak during citizens-to-beheard. Usually there are fewer than 10.

Throughout the process, representatives from either side of the ideological aisle approached the microphone to cheers from their compatriots, who stood in the back waving signs that said either "God Created 2 Genders: Male and Female" or "Protect LGBTQIA Students."

Both sides held signs. Both spoke passionately. Only one side misbehaved. It was those who were there explicitly claiming to be doing God's business, calling for the repeal of the non-discrimination policy who were raucous and rude. They shouted over the speakers, "boo'd" gay teenagers who were there to say "thank you" to the school board for the new language in the non-discrimination policy. They yelled at the school board president (a Catholic urban missionary who has taken a vow of poverty to live deep on our city's Westside and minister to her neighborhood), saying that she is untrustworthy and disrespectful.

With exactly two exceptions, those expressing support for the policy did not shout. They did not "boo." They left the podium when their time was up.

I won't go into the fear-mongering, pseudo science, and invoking the judgment of God. That all happened too, and it was painful. 
Teenagers heard adults call them mentally-ill, depraved, and suggest that they were only gay or transgender because their parents had neglected them.

One woman, wearing a Christian t-shirt, shouted that transgender students didn't deserve to be protected.

Students were crying. Their parents, far from neglectful, were furious.

After accusing the school board of being covert and sneaky, the protestors excused themselves from the very public forum in which such decisions are made. The school board went about its live-streamed business in front of the sparse crowd that remained, fully transparent, just like they were on the day the policy passed.

Christians, we cannot just show up when there's a battle we feel like fighting. If the school board is your battlefield, you need to be at every meeting. The teacher's union is there. Representatives from the mayor's office are there. Where are we, church?

If you are one of those Christians reading this and saying, "The media always focuses on the extreme Christians..." I ask again, where are you? Where are you reasonable Christians when I'm taking quotes and begging you to go on record and speak up for the Gospel?

Later, on the steps of the SAISD administration building, the pastor leading the protest said, "We don't hate the LGBT community just because we believe there are only two genders."

The students gathered didn't buy that logic. Not after what they had just heard inside. That same pastor had implied that they were predators, boys masquerading as girls for nefarious purposes, including "recruiting kindergarteners."

Into my camera students expressed, with great clarity, the Church's major roadblock in reaching the transgender community: the Church won't admit that they exist.

Conservative Christians are sending the message loudly and clearly: we can't minister to your soul until we fix your sexuality. Until then, you are dead to us. Your feelings don't matter. You don't even exist.

The tough reality for the Church, is that transgender people do exist. We should consider the possible consequences of writing off an entire segment of humanity.

I have never been more sympathetic with the heterosexuals who leave the church over this issue. I have never wanted to be less identified with my brothers and sisters.

Two things kept me in the Church on Monday night. 
First, my entire worldview does not hang on society's acceptance or rejection of gay marriage. It's an issue the church can work through; we don't have to come to peace about it today. We're starting in a pretty polarized place, and we need to have some tough conversations, but I think we can bear with each other.

I believe that Jesus brings hope for the LGBTQIA community. Not hope that one day they can be heterosexual. Hope that they can know the same peace, acceptance, and love that I have found, because they need Jesus just like I do. Not because of their sexual identity, but because of their humanity.

The other thing that kept me in the church was the work of a single pastor. The one evangelical pastor who showed up, not to speak from the podium, but to move around the room hugging students, telling them God loves them, and letting them know that he was there to listen if they ever wanted to talk about faith.

Bekah McNeel is a native San Antonian and journalist. She reports on education inequities for Folo Media. Mother of two, wife of one, and reader of many, Bekah is constantly exploring with books and kids in tow. 